\title{
Om N. F. S. Grundtvig og G. P. Brammer
}

\section{Af Anders Eskedal}

Nedenstående artikel forelægger et nyfundet brev fra Grundtvig til en af hans unge disciple i 1824. Artiklen føjer det ind i en offentliggjort korrespondance mellem de to og beskriver deres sammenstød og Brammers følgende brud med den spirende grundtvigianisme og derved også med Grundtvig selv.

\section{Yderside}

S. T.

Hr Candidat Bramer ${ }^{1}$

i

Kiøbenhavn

27de Febr. 1824 [på hovedet]

Inderside (brevtekst)

\section{Chvn $27^{\text {de }}$ Febr 1824}

Det giør mig ondt, kiære Ven! at De er saaledes syg, jeg troede efter det Foregaaende, at det kun var lidt Forkiølelse, der holdt Dem inde, ellers havde De alt seet mig -

Pengene har jeg rigtig faaet, ogsaa Kvitteringen fra Hjørlunde, og at jeg ikke igien sendte en for de 16 Rd kom af, at jeg i Almindelighed slet ikke kan befatte mig med at udstæde saadanne, der vist ei heller kan behøves, men her skal jeg da, for Deres Skyld, giøre en Undtagelse Tak for Cataloget, som jeg skal giennemsee, til vi tales ved -

Herren velsigne og bevare Dem, og udføre Dem snart af den nærværende, som af [af] al mødende Modgang til at takke Hans Navn, af Hvem al Faderlighed har sit Navn og sin Kraft!

Deres Ven

N. F. S. Grundtvig 
Ovenstående lille Grundtvig-manuskript fandt jeg under mit arbejde med katalogisering af arkivet efter professor Anders PontoppidanThyssen. Arkivet, som indtil videre er hjemmehørende på Aarhus Universitets teologiske fakultet, indeholder (resterne af) hans stort anlagte religionssociologiske samling, heriblandt en væsentlig samling personal- og vækkelseshistoriske aktstykker: breve, prædikener, levnedsskildringer og andet. Her er for eksempel adskillige årgange af Valdemar Brückers prædikener, taler og artikler, og her er en større samling prædikener af og breve fra og til præsten Hans Sveistrup og hans søn Poul Theodor Sveistrup. I dette arkiv lå også ovenstående lille Grundtvig-manuskript, der sagligt føjer sig ind i de breve fra og til N. F. S. Grundtvig, som er udgivet af Georg Christensen og Stener Grundtvig ( $B G$ I-II). Når det ikke er kommet for dagens lys før nu, kan det skyldes, at det har været i privateje, indtil Pontoppidan-Thyssen fik det. Jeg har ikke kunnet finde det i Steen Johansens fortjenstfulde Registrant over N. F. S. Grundtvigs papirer. Jeg fandt det i et mørkeblåt papomslag sammen med en gul lap papir med segl og skriftprøve af Grundtvigs svoger, ritmester Carlsen, Gl. Køgegaard, i forbindelse med Grundtvigs 70 års fødselsdag. Nederst herpå havde en fremmed hånd tilføjet "N. F. S. Grundtvig, præst (1783-1872)".

Grundtvigs brev til kandidat Brammer er skrevet på tykt oktavpapir. Ikke desto mindre har det været foldet sammen, som man gjorde dengang, så det blev sin egen konvolut. Udenpå skrev man blot: Til $\mathrm{NN}$ i N-by - det kunne man klare sig med den gang, selv i landets hovedstad!

Hvem er så denne kandidat Brammer? Jeg går ud fra, at det er den senere seminarieforstander og mangeårige Århus-bisp Gerhard Peter Brammer, ${ }^{2}$ som i sin ungdom var tiltrukket først af Grundtvig og siden af Mynster, før han til sidst valgte Kingo og den lutherske ortodoksi, som sit blivende kristelige stade. Som kirkelig embedsmand fulgte han den Mynster-Martensenske linje og blev blandt andet en stor modstander af ideen om valgmenigheder. Han var født i 1801 i Hillerød, og da han og Grundtvig først begyndte at veksle breve i 1821, var han endnu stud. theol. ${ }^{3}$ Brammers ungdomserindringer er udgivet af hans ven Johs. Kok (Kok 1884), ${ }^{4}$ som i sit forord redegør for arbejdsprocessen.

Om sin kristelige udvikling fortæller han i ungdomserindringerne, at en personlig kristen blev han med ét slag under festlighederne ved 300-års jubilæet for reformationsteserne fra Wittenberg. Da han på en gåtur hørte Holmens Kirkes klokker, slog det ham: Du skal blive kristen! Og du skal blive præst! Og så måtte han jo i første omgang 
tilmelde sig teologistudiet på universitetet, selv om han havde haft under overvejelse at læse jura (Kok 1884, 105).

Grundtvigs prædiken "Hvorfor kaldes vi Lutheraner?" fra $1812 \mathrm{og}$ digtet "I Wittenberg, i Sachsenland" fra 1813 kendte Brammer ikke på det tidspunkt, men han læste og blev grebet af Grundtvigs "Bibelske Prædikener" fra 1816; især prædikenen over Rom 8-9 blev ham en "Livsprædiken" og lærte ham at indse rationalismens vildfarelser. Således gik det også med prædikenen om, "hvorvidt vi trænge til en Reformation som den i Luthers Dage" (Kok 1884, 106 f). Kirkegang og opbyggelse havde Brammer i årene efter 1817 hos Mynster (Kok 1884, 108). På side 113-114 får tidens førende prædikanter nogle uforbeholdne skudsmål: Mynsters prædikemåde eller fremtoning kaldes "ufri", provst Gutfeldts "levende", Clausens "afdæmpet", professor Brorsons "affekteret", og Grundtvig "tjenstledig". Man må jo huske, at Grundtvig ikke siden 15. august 1813 havde haft fast embede, og da kun som kapellan, og altså ikke havde nogen fast prædikestol i hovedstaden. Da Grundtvig kom til Christianshavn, sluttede Brammer sig til hans menighed. Om bruddet med Grundtvig skal vi siden fă at høre, men Johs. Kok anfører i en note (Kok 1884, 107), at kærligheden til Grundtvig bevarede Brammer hele livet trods alle konflikter både med Grundtvig selv og med hans kirkelige parti.

Brevskrivningen mellem Brammer og Grundtvig påbegyndes 13/5 1821 med et brev fra Brammer (brev 240, $B G$ II, 21 ff.), hvori han udøser sit hjertes skuffelse over ikke at have vundet den sangkonkurrence, som samme år var blevet udskrevet til Luthers minde. ${ }^{5}$ Sit bidrag havde han ladet Grundtvig gennemse og gøre rettelser, ja en udvidelse i, og så skulle den jo være hjemme. Men Grundtvig havde advaret ham mod at tage det for givet og havde altså fåt ret. $\mathrm{Nu}$ skriver Brammer om, hvordan han brugte nogle timer i Rosenborg Have på at komme til rette med sit nederlag, og han husker i den forbindelse med glæde samtalen med Grundtvig, der endte med, at denne under håndspålæggelse havde nedbedt Guds fred over ham. Så i skrivende stund har Brammer igen kastet sig over sin eksamenslæsning. Mod slutningen af brevet tilbyder Brammer Grundtvig sin hjælp, formodentlig med noget korrekturlæsning, idet det dog ikke siges præcist, hvad det drejer sig om.

Herpå svarer Grundtvig den 23/5 (brev 242) med et: Det var da godt, det gik, som det gik! Det er ikke godt at vide, hvilke griller en sejr havde sat i Dem... Lidt barsk indleder han: "Tak for den Oprigtighed, hvormed De tilstaaer Deres Feil!" ( $B G$ II, 25). Det er ikke bare en tillidserklæring, men også et vidnesbyrd om, at Brammer ved denne lejlighed har lært både sig selv og ungdommens lidenskaber lidt bedre at kende. Han vejleder desuden den unge Brammer til ikke at indgå 
væddemål, medmindre han er meget sikker i sin sag. Alligevel vil Grundtvig gerne se student Zahles vindersang, "som jeg kun har ringe Tanker om, da han fornedrer sig til, i Haab om to Skilling meer [i

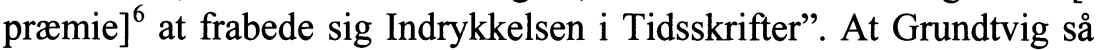
senere som præst ved Vartov skulle stifte årligt bekendtskab med den, kunne han ikke vide i 1821.

Grundtvig opfordrer herefter den unge Brammer til at lægge "saa meget, De kan, Vind paa Grund-Sprogene og Kirke-Historien, thi den Fremgang man deri giør, er Vinding for stedse" og tilføjer, at grammatikalske øvelser făr man ikke tid til senere hen, og i historien skal man hurtigt skaffe sig et overblik, som man siden kan fylde på. For Grundtvig er historien "den egenlige, dvs. reelle, Kundskab", som bør læses "helst efter de ældste Kilder og helst i Grundsproget (...) eller i den troeste Oversættelse, De kan faa" ( $B G$ II, 26), hvis det skal være ordentlig videnskab: "Det er en aandelig Udenlands-Reise, som i de fleste Tilfælde giør den legemlige overflødig (...) og (...) lærer os at kiende vore Kræfter og Anlæg, og udvikler, under Guds Velsignelse, alt hvad Godt der er i os" ( $B G$ II, 26).

Det er således ikke rigtigt, heller ikke om den modnere Grundtvig, at kalde ham antiakademisk; det akademiske arbejde må ifølge Grundtvig sigte på det praktiske liv og ikke blive et mål i sig selv. Så højt sætter han altså den historiske beskæftigelse. Angående korrekturlæsningen siger han tak for tilbudet, men der er desværre ikke ret meget at læse på for tiden.

16/6 skriver Brammer igen til Grundtvig (brev 247) og takker for ansporingen til studeringerne, især til kirkehistorie. Netop historie har han altid haft god nemme ved, men har jo måttet indse, at "min $\mathrm{Hu}-$ kommelse taber sig, alt som Dømmekraften voxer", så han har forglemt det meste, hvilket han overvejer måske blot skyldes dårlig undervisning og dårlige lærebøger.

Kristi Himmelfartsdag havde han været i den franskreformerte kirke i København og havde hørt pastor Monod, som viste sig at holde en solid, bibelsk afskedsprædiken. Til sidst udtrykker han sit stigende håb om det kristne Grækenlands befrielse fra tyrkerne. ${ }^{7}$

Herefter ligger brevskrivningen åbenbart stille, indtil Brammer igen skriver 9/2 1822 (brev 251). Han tiltaler Grundtvig som sin kære og uforglemmelige lærer og mener selvfølgelig sin kristelige lærer, sådan som brevet videre henne afslører. Han spørger, hvorfor Grundtvig ikke har udgivet noget skriftligt siden Bjovulfs-Drapen fra 1820, og han tilføjer, at i mangel af at kunne fă Guds ord at høre rent og purt i kirkerne må han ty til Grundtvigs gamle prædikener. Hvad han videre siger om sit eget kristenliv, afslører, at hans teologi allerede her begynder at blive ortodoks. Han bebrejder sig sin dømmesyge og 
svaghed i bønnen og spørger, om det er åndelig dårligdom, at han har svært ved at huske, hvad han har læst med henblik på eksamen, og vender sig til Grundtvig, om denne kunne lære ham "at vandre i Aanden".

Der kommer først svar fra Grundtvig den 30/4 (brev 252). Grundtvig undskylder langsomheden og begrunder den dels med embedsforretninger, dels med det glædelige, at han er blevet far. ${ }^{8}$

I øvrigt siger Grundtvig, at "i Aandens Verden er Følelsen af vore Mangler den nødvendige Betingelse for Hjelp fra den Gud, der kun vil være stærk i dem, der føle sig svage” ( $B G$ II, 42). Det belægger han med flere bibelhenvisninger og tilføjer, at det med hukommelsen og eksamenslæsningen ikke har med denne sag at skaffe; her gælder det bare at klø på og lægge sin sag i Herrens hånd. Vore evner kan misbruges "til en Ærejagt for os selv", og alle vore evner må opofres Herren, hvis han virkelig skal bruge dem, men så gør han det til gengæld også. ${ }^{9}$

Der må være nogle breve i korrespondancen, som Georg Christensen og Stener Grundtvig ikke har ladet trykke, for i det næste brev, af 4/10 1822 (brev 260) henviser Brammer til "begge Deres sidste Breve" ( $B G$ II, 51). Han taler om den "Leve-Plan, jeg, saa vidt det staar til mig, nu har at følge", og som Grundtvig faderligt har kommenteret på, men hvad, den går ud på, fremgår hverken af de trykte breve eller erindringerne. Ellers er brevet endnu et vidnesbyrd om taknemmelighed over for Grundtvig for hans vejledning. Det indbyrdes forhold omtales nu også fra Brammers side som et venskab.

Det næste brev, der er trykt, er fra Grundtvig og dateret 21/11 1823 (brev 273). Grundtvig er nu kommet til Christianshavn som præst ved Vor Frelsers Kirke, og man kunne vente en nærmere kontakt mellem ham og Brammer, da de nu begge er i København. Grundtvigs hensigt med brevet er at kommentere Brammers prædikener til langfredag, 1. påskedag og 1. pinsedag. ${ }^{10}$ "En Langfredags og en Paaske-Prædiken er desuden vel de bedste Kiende-Mærker paa, i hvilken Aand der tales", skriver Grundtvig indledningsvis ( $B G$ II, 68), men det bliver nu mest pinseprædikenen, der tages fat på. "Grundvolden til gode Prædikener fandt jeg, thi det er (...) paa Propheters og Apostlers Grundvold (...) der skal bygges" (ibid.). Troen på Helligånden har ifølge Grundtvig altid været det, Brammer har haft vanskeligst ved, og derfor mangler prædikenerne det Helligåndens liv, uden hvilket "Ordet [er] dødt for os, og Døden i det hele er vor Overmand” (ibid.). Både Brammers sprog og tankegang er dog i det store og hele upåklageligt, og Grundtvig betragter derfor pinseprædikenen som en "Alvors Tale (...) til Dem selv" (ibid.), der indgyder ham godt håb om, at det snart skal blive glædeligt anderledes for den unge ven. For at afklaringen kan ske, må 
Brammer imidlertid tage et spring fra at indrømme ordets sandhed og til at tro på ordet, et spring som fra døden til livet. Mere end en følelse af, at uden Jesus kan vi intet i vor saligheds sag, behøves altså ikke i et oprigtigt, sandhedskærligt hjerte, og dette bestyrkes ifølge Grundtvig så meget mere af, at Jesus beder for os hos Faderen netop om dette. Til denne forbøns nåde henviser Grundtvig Brammer, og så vil "det Stive, Tvungne, snart for Ængstelige, snart for Dristige i Bekiendelsen og Forkyndelsen"(BG II, 69) med tiden forsvinde. Grundtvig skal også lige have sagt, at han ikke kan lide, at Helligånden kaldes "den"! Til sidst beder han Brammer tænke over, at "det er Aanden, den HelligAand, som giør levende, at Guds Ord er Liv og Aand, og at Jesus, men ogsaa han alene, kan hjelpe os!" Christensen \& Grundtvig har vel optaget brevet, fordi det giver en kort, samlet og afsluttet redegørelse for en bestemt teologisk problemstilling: Hvordan man kommer til tro, eller hvordan man kommer fra teori til sandhed i troens sag ( $B G$ II, 68 ff.).

Det næste brev i samlingen er fra $15 / 61824$ (brev 281) og kan behandles i samme omgang, da også det handler om Brammers prædikener. Da har Grundtvig modtaget en ukendt prædiken - muligvis den prædiken til Pastoralseminariet, som han i et Post Scriptum til brev 273 bad om at få til gennemsyn, før den skulle holdes, og fundet, at den "i sine Elementer, i sin Grund er christelig, og et virkeligt Fremskridt", så han er "vel fornøiet" ( $B G$ II, 82). Også dens disposition er godkendt, mens udredningen forekommer lidt for spekulativ. "Men da Udviklingen i Ord, naar den skal være livlig, maa være et Billede af Udviklingen i Aand, anmærker jeg kun Sligt til Erindring, ei til Anvendelse for Øieblikket" $(B G \mathrm{II}, 83){ }^{11}$

Så er vi nået frem til det nyfundne brev fra 27/2 1824. Skulle vi følge kronologien i Georg Christensens og Stener Grundtvigs samling, måtte det få plads som nr. 274b, eftersom brev 274, til Henrik Steffens, er dateret 1823, og brev 275, fra Frederik Münter, er dateret 14/5 1824. Igen har vi kun ganske få ydre oplysninger. Brammers sygdom - som har været alvorligere end en forbigående forkølelse - hører vi kun om her. De økonomiske mellemværender, som Grundtvig egentlig ikke er glad for at have, stammer fra handel med Hjørlunde præstegård, hvor Brammers morfar, Johannes Jensen, var præst 1786-1823. Han var syg det meste af 1823 og døde sidst på året, ${ }^{12}$ og det omtalte katalog kan således stamme fra dødsboet; det kan være listen over hans bøger. Det har dog ikke været muligt at bestemme, hvad Grundtvig har modtaget de 16 rdl. for.

I juni 1824 er forholdet mellem Brammer og Grundtvig altså endnu godt. Dette fortsatte dog ikke. Brammer skriver i sine ungdomserindringer side 150-156 om bruddet, og Grundtvigs svar eller 
forholden sig til sagen fremgår af brev 291, der dateres så tidligt som til den 9/7 1825.

\section{Først Brammer:}

Stiftsprovst H.G. Clausen, i folkemunde kaldet den lille pave, havde som censor ved Pastoralseminariet været hård mod især den anden af de prædikener, Brammer skulle holde dér. Han "vilde ikke uleilige sig med at kritisere en Kandidat, der troede sig hævet over al Dadel, og vilde ogsaa fritage Alumnerne derfor" (Kok 1884, 150). Clausens kirkelige modstander, N. F. S. Grundtvig, "hvis Tilhængere syntes at tillægge ham pavelig Ufeilbarlighed" (Kok 1884, 151), behandlede ikke Brammer blidere. "Om vort Forhold til hinanden skal jeg, om Gud vil, oftere komme til at tale", skriver Brammer videre, men det bliver i ungdomserindringerne kun til to afsnit, side $151 \mathrm{ff}$. samt side $185 \mathrm{ff}$. Han refererer, hvad også er fremgået af brevene, at Grundtvig kommenterede hans prædikener, skrev små kritiske bemærkninger på dem, men ellers roste forkyndelsen for at være "skriftmæssig". Det kom endog til, at Brammer lånte Grundtvigs prædikestol i Vor Frelsers Kirke en dag, da Grundtvig havde fået forfald. Han skulle til sin svoger Poul Egede Glahns indsættelse som residerende kapellan i Garnisons kirke sommeren 1824. Midt under prædikenen kommer Grundtvig, muligvis fordi han havde lovet at forestå messetjenesten, hvad Brammer jo som uordineret ikke måtte, og får altså en halv prædiken at høre. I præsteværelset bagefter forekommer Grundtvig kold og nedladende og ganske tavs. Han făr prædikenen med hjem til gennemsyn, og en uge efter møder Brammer op hos ham for at få en vurdering. Grundtvig ligner stadig et tordenvejr; han er ikke syg, siger han, snarere vred, men først, da han finder den lånte prædiken frem, opfatter Brammer, at det er den, der er årsagen. Grundtvig slår ned lige på det sted, Brammer var kommet til, da han kom til stede, men er ifølge Brammer løbet med en halv vind, idet "jeg fremsatte nogle rationalistiske Meninger for at gendrive dem"( Kok 1884, 154). Efter det hørte kunne man godt forstå Grundtvigs fornemmelse af vrang lære og hans tavse forbitrelse på dagen, "men dersom han virkelig havde læst mit Manuskript i den forløbne Uge, kunde jeg kun forklare hans Misforstaaelse ved, at Hidsighed (...) bringer et ellers forstandigt Menneske fra Sands og Samling", siger Brammer (ibid.). Men han skriver, at han "memorerede" 13 på prædikestolen, og det kan betyde, at der blev sagt noget andet, end der var skrevet. Da Brammer vil have et ord indført for at rette misforståelsen, bliver Grundtvig ved med at "skrige op i en Timestid" med bl.a. en del anklager mod Brammers karakter og vil aldeles ikke høre tale om nogen retledning. Da Grundtvig så sagde, at han de næste mange år burde afholde sig fra at 
prædike, svarede Brammer, at det havde han ikke tænkt sig, han havde både ydre og indre kald dertil, men det skulle muligvis ikke være $\mathrm{i}$ København, og han var for øvrigt ked af, at han havde modtaget Grundtvigs opfordring til at prædike for ham (Kok 1884, 155). Da Brammer nu ville føre samtalen hen på noget andet og forelagde Grundtvig en regning på nogle bøger, denne havde bedt ham købe på auktionen efter hans bedstefar, holdt Grundtvig ham endnu en straffeprædiken mod pengebegærlighed. "Saaledes endte denne Sammenkomst med, at Grundtvig satte mig i den lille Band, efter at Clausen havde lyst den store Bandsættelse over mig" (Kok 1884, 156).

Sådan kunne Grundtvig altså virke, hvis man uforberedt faldt $\mathrm{i}$ hans kløer eller blev offer for hans dårlige humør. Det har andre også fået at mærke, og det er også sket, at folk, der besøgte ham, blev udsat for den uhøflighed, at de ikke blev tilbudt en stol. Brammers fremstilling er selvfølgelig ikke neutral, for han gør sig umage med at fremstille sig selv som godtroende og intetanende og uforstående, men han har utvivlsomt fået et chok over den behandling, han fik. Endnu et par gange prøver han at få sat Grundtvig i et dårligt lys; på side 154 vil han næsten gøre ham til bibelkritiker, og på side 164-165 refererer han Grundtvigs rosende udtalelser om sin fætter, Henrik Steffens, idet han tilføjer, at da denne i sommeren 1824 var i Danmark, sad Grundtvig roligt $i$ sit studerekammer og ville ikke engang se ham - modsat for eksempel professor Sibbern. ${ }^{14}$ Bruddet med Grundtvig har således sandsynligvis været en større smerte for Brammer, end han umiddelbart vil give det udseende af. Men man kan ikke fortænke ham i at sige fra over for Grundtvigs uforbeholdne og temmelig grove anklager!

\section{Dernæst Grundtvig:}

Den 9/7 1825 gør Grundtvig i brev 291 et forsøg på at få det gode gamle forhold genoptaget: Han kan ikke forstå, at han ikke har set Brammer så længe, og har tænkt "allehaande" derved, men altid endt op med, at "han kommer dog vel engang igien, saa man kan faa ham ordentlig i Tale". Det sammenstød, som Brammer tog anstød af, var altså en misforståelse. Grundtvig har tænkt selv at gå til Brammer, men blev tilbageholdt af den tanke, at hvis ikke Brammer er forfængelig og storagtig, så må han indse, at han, Grundtvig, ikke har villet gøre ham noget ondt. Man kan imidlertid spørge sig selv, om Grundtvig tøvede, fordi han ikke turde henvende sig til Brammer. Vi ved, at han havde svært ved at gå på husbesøg, og Brammer var som sagt ikke alene om at opleve, at han kunne være vanskelig at omgås. Folk, der ville ham noget, måtte derfor komme til ham. Havde Grundtvig en slags social fobi eller en psykisk disposition, så han havde svært ved at knytte sig følelsesmæssigt til andre? ${ }^{15}$ Han siger således selv: "Vist 
nok er det meget mueligt, at jeg, da De sidst var hos mig, kan have brugt haardere Ord, end ret og nødvendigt var; thi det pleier at gaae mig saa, naar jeg bryder overtvært, og siger mine Venner, hvad jeg længe har opsat" ( $B G$ II, $104 \mathrm{f}$.). Dette er så langt, han kommer $\mathrm{i}$ retning af at give en egentlig undskyldning for upassende adfærd, og han står i øvrigt ved, hvad han sagde. Men i et helt år har Grundtvig været uvis, om de stadig var venner, og, indrømmer han, "Lidt af Fader-Følelsen (...), faae vi immer for de Yngre, der har knyttet sig til os, og er blevne os kiære", men i det mindste er det godt, at Brammer "ikke vitterlig har skyet" ham. Brevets første sætninger antyder, at Brammer stadig kommer i Frelsers kirke.

Dette brev må være svar på et fra Brammer, for han har spurgt til Grundtvigs reaktion på hans dissertats, det vil sige hans afgangsopgave fra Universitet. Dissertatser var på dette tidspunkt endnu skrevet på latin, men Grundtvig synes, den er så god, at han foreslår en offentliggørelse i Rudelbachs teologiske månedsskrift i en dansk oversættelse eller bearbejdelse. $\mathrm{Og}$ så slutter brevet forsonligt med en stående indbydelse og en bemærkning om Grundtvigs børn, som har overvundet en omgang kighoste. Dette er det sidste brev mellem de to $\mathrm{i}$ Christensen \& Grundtvigs samling.

Så skriver Brammer i sine ungdomserindringer side 185-192 om sin studentertids største kirkehistoriske begivenhed, Kirkens Gienmoele og striden derom. Fremstillingen er imellem linjerne om ikke for Clausen, så i hvert fald imod Grundtvig. Han siger, han vil være fair og upartisk, dels, fordi det skylder man parterne, dels på grund af den "Pietet", han fra sin ungdom skylder Grundtvig, og det gode forhold, han med tiden fik til H. N. Clausen, dels af hensyn til "Dommens Trin, som nærmer sig Døren" og dels af hensyn til de impliceredes børn og børnebørn (Kok 1884, 186 f.). Kirken Gienmole udkom 26/8 1825, og den første reaktion på det kom fra den senere fængselspræst Carl Holger Visby, der tog initiativ til en støtteadresse til Clausen. Den søgte Brammer med held underhånden at få gjort så almen, at alle teologistuderende kunne være med. Adressen fik 88 underskrivere. En af de første dage af september mødte der imidlertid et par unge mennesker op hos Brammer og ville skrive under på en støtteadresse til Grundtvig, som, de mente, han havde taget initiativ til. Også ved Grundtvigs fødselsdag 8/9 kom A. G. Rudelbach og Jens Holm og ville have Brammer med ud for at sige til lykke. Brammer ansås altså fremdeles for Grundtvigs discipel, og føromtalte sammenstød var ikke blevet kendt. I sin omtale af et brev fra Grundtvig, som Brammer antager er "inspireret af hans Hustru Elise", tilføjer han da også, at beslutningen om at bryde med Grundtvig for bestandig endnu ikke var truffet. Brammer var derfor også taget med ud for at fejre Grundtvigs 
fødselsdag, "men Forholdet mellem os var noget tvungent og kunde aldrig, som det Følgende skal vise, blive det gamle, ligefremme, fortrolige og stundom muntre, hvorved jeg nok havde vundet Yndest hos hans Kone" (Kok 1884, 189). Ånden i selskabet svarede ikke til Brammers forventninger, han fandt stemningen mat, ikke et ord om den mageløse opdagelse af trosordet, kun snak om sagen mod Clausen. Senere i samme måned kom Ludvig Müller fra et selskab af Grundtvigs venner, hvor man gerne ville have Brammer med. Brammer kom, tøvende og tvungent; man bad ham på mødet om at forsvare Grundtvig mod Peder Sørensen Halds angreb for ved Kirkens Gienmoele at være overløbet fra bibelprincippet til traditionsprincippet i teologien, altså fra luthersk til katolsk kristendom. Men da Brammer var så halvvejs enig med anklagen, kunne han jo ikke godt forsvare Grundtvig imod den. "Man gav mig at forstaa, at min Vægring vilde optages som et Frafald fra Grundtvig. Men Sandheden var, at han var frafalden sig selv" (Kok 1884, 192). Således indtraf det endelige brud.

Dette blev Brammers varige anke mod Grundtvig. Han selv fastholdt bibelprincippet. At Grundtvig så $i$ sin praktiske bibelbrug forblev noget nær fundamentalist er en anden sag. Men vejene måtte skilles. Meningen her var kun at aftrykke et nyopdukket brev og give et indblik i en brevskrivning og et venskab, som altså ikke kunne stå distancen.

\section{Forkortelser}

$B G$ I-II: Georg Christensen og Stener Grundtvig (udg.) (1924-26), Breve fra og til N. F. S. Grundtvig, 1807-1872, bind 1-2, København.

GI: Svend Grundtvig (udg.) (1882), Grundtvig og Ingemann: Brevvexling 1821-1859 / udgiven og indledet af Svend Grundtvig, København.

Registranten: Grundtvig-Selskabet af 8. September 1947 og Det danske Sprog- og Litteraturselskab (1957-64), Registrant over N. F. S. Grundtvigs papirer, fasc. 249, København.

SJ I-IV: Steen Johansen (1948-54), Bibliografi over N. F. S. Grundtvigs Skrifter, bind 1-4, København.

\section{Litteraturliste}

\section{Voerker af N. F. S. Grundtvig}

Brandt, C. J. (udg.) (1877), Kirkelige Leilighedstaler: af N. F. S. Grundtvig, København.

Christensen, Georg og Grundtvig, Stener (udg.) (1924-26), Breve fra og til N. F. S. Grundtvig, 1807-1872, bind 1-2, København.

Grundtvig, Svend (udg.) (1882), Grundtvig og Ingemann: Brevvexling 18211859 / udgiven og indledet af Svend Grundtvig, København. 
Grundtvig-Selskabet af 8. September 1947 og Det danske Sprog- og Litteraturselskab (1957-64), Registrant over N. F. S. Grundtvigs papirer, fasc. 249, København

Johansen, Steen (1948-54), Bibliografi over N. F. S. Grundtvigs Skrifter, bind 1-4, København.

\section{Voerker af andre forfattere}

Dansk Biografisk Leksikon (1888), bd. 2 og alle senere udgaver.

Kok, Johs. (1884), Biskop. Dr. Theol. G. P. Brammers Ungdomsliv, København.

Wiberg, S. V. (1870), Personalhistoriske, statistiske og genealogiske Bidrag til en almindelig dansk Preestehistorie eller alphabetisk ordnet Fortegnelse over alle Sognekald, Sognecapellanier, Hospitalsprcesteembeder o.s.v. i Danmark med Anførelse af Prosterne i dem siden Reformationen og Efterretninger om deres Personalia o.s.v., bd. 1-3 + supplement, Odense

Vogel, Ulrich (1993), Bankede på ved Paradis. N. F. S. Grundtvigs kriseoplevelser, København

\section{Noter}

1 Grundtvig staver her ved en fejl Brammers efternavn forkert.

2 Om Brammer kan læses, bl.a. i Dansk Biografisk Leksikon (1888), bd. 2 og alle senere udgaver.

3 De breve mellem Brammer og Grundtvig, som er optaget i Georg Christensens og Stener Grundtvigs kronologisk opbyggede samling, er nr. 240, 242, 247, 251, 252, 260, 273, 281 og 291 (BG II, 21-106).

4 Brammer har skrevet hovedteksten, mens noteapparatet skyldes Kok, som har udgivet bogen. Heri er i vor sammenhæng navnlig s. 105-107, s. 151156 og s. 185-192 interessante.

5 Om denne konkurrence og om den tradition at fejre Luthers minde $\mathrm{i}$ Vartov kirke på reformationsdagen 31. oktober skriver C. J. Brandt i et efterskrift til Grundtvigs Kirkelige Leilighedstaler (udg. 1877): 1821 udsatte en enke C. Quist, som tidligere gavmildt havde betænkt Københavns fattigskoler, en præmie for den bedste mindesang om Morten Luther, "som den gode Gud udrustede med visdom, lærdom og et uforandret mod i dødstimen, for at skaffe den hellige skrift frem for alle slægter, så nu kan alle, som vil, i sin redelig enfoldige tro finde vej til Guds rige, så klar som solen på den klare himmel”. Præmien tilkendte hun student S. Zahle for sangen: "I Betlehem var lyset tændt" og erhvervede sig kongelig tilladelse til, at den måtte blive afsungen i Vartov kirke hvert år den 31. oktober af børn fra fattigskolerne, imod at hun stiftede et legat på 250 rdl., for hvis renter dels organisten skulle lønnes, dels sangen efterhånden optrykkes. Året efter føjede hun hertil andre 200 rdl., hvis renter skulle tilfalde præsten, og dette gav anledning til, at Grundtvig i den menneskealder, han var præst ved Vartov stiftelse, til sin høje alderdom årlig holdt 
de mindetaler over Luther, som her meddeles, for så vidt der findes fuldstændige udkast til dem.

6 Min tilføjelse.

7 Den græske frihedskrig 1821-1829 førte til Grækenlands selvstændighed 1830. Den første nygræske statsdannelse omfattede Peloponnes og Mellemgrækenland. Det nuværende Grækenland er fremkommet af flere omgange frem til 1947.

8 Sønnen Johan Grundtvig blev født på "Confirmations-Søndagen" = 1 . Søndag efter Påske = 14/4 1822 .

9 Brammer har åbenbart i sit sidste brev vedlagt en universitetsopgave til kommentering. Det får Grundtvig imidlertid ikke tid til, men han noterer dog, at de to er enige om opstandelsestroen.

10 Disse prædikener kunne være interessante at se, men er ikke udgivet, ej heller i Brammers postille fra 1841. De er efter alt at dømme holdt i Hjørlunde som aflastning for Brammers syge bedstefar. Det er vist også kun Kaj Munk, der har turdet udgive prædikener fra tiden før han blev præst.

11 Brevet afsluttes af diskussioner af specifikke formuleringer i den pågældende prædiken.

12 Yderligere oplysninger om Johannes Jensen kan findes i Wiberg 1980, 644.

13 Ved en trykfejl står der: "memorede".

14 Dette er dog ikke rigtigt, jf. Grundtvigs brev til Ingemann 26. november 1824 (GI, 34-36).

15 Ulrich Vogel har i sin ph.d.-afhandling Bankede på ved Paradis (1993) argumenteret for det sidste; dette kan være grunden både til hans valenhed med husbesøg og til hans lejlighedvis aparte optræden, når folk opsøgte ham. 